\title{
MULTICULTURAL APPROACH TO EDUCATION
}

\author{
Anzhelina Koriakina \\ North-Eastern federal university, Russia
}

\begin{abstract}
The article discusses the definition of a multicultural approach to education. The views of foreign and Russian researchers on this problem are represented. Features of amulticultural approach - dialogue of cultures in historical and contemporary context, cultural pluralism, multi-ethnicity - are showed. It is concluded that in Russia the term "multicultural approach to education” is used in the meaning ,multi-ethnic".
\end{abstract}

Keywords: cultural identity, cultural pluralism, cultures of various ethnic groups, dialogue of diverse cultures, multicultural approach to education, multi-ethnicity.

\section{Introduction}

The growing social value of learning and mastering a foreign language led to the emergence and rapid development in the theory and methodology of teaching foreign languages such direction as multicultural approach to education. It is a multicultural approach to education of students by means of a foreign language that plays an important role in their development, education and cultural self-determination.

However, an analysis of a number of scientific papers on the issue of multicultural education shows that scientists have not reached a consensus as to what is a multicultural approach to education, and how it should be implemented. Different researchers emphasize different conceptual elements that they believe should define a ,multicultural approach" to education, have a different view of its goals and objectives, and have divergent views on how a multicultural approach to education can be implemented.

In this paper, we attempt to propose our vision of the essence of a multicultural approach to education.

\section{Background}

In many respects, the development of a multicultural approach to language education is associated with the emergence of the socio-cultural approach to teaching foreign languages. Unlike some other existing cultural approaches, her approach draws attention to the possibility of not only learning a foreign language, but at the same time learning the culture of the bearers of the studied language, including their ethnic, social, and religious characteristics.

We define a multicultural approach to foreign language teaching as one which includes the aspect of learning the culture of the target language. This definition, in our opinion, is especially relevant given the socio-cultural realities which exist in the various republics of the Russian Federation. The learning 
environments in most high schools across Russia are highly multicultural, which, in turn, creates a need for designing educational approaches which can address the unique needs arising within such contexts.

The problem of a multicultural approach to education has gone through several developmental stages. First, it was limited to the problem of creating schools that reflected the national interests of particular ethnic groups; then, the problem was broadened to creating educational institutions that were multiethnic. Currently, the problem is considered from even a wider perspective that considers human culture as a whole where there is dialogue between cultures on a wide spectrum. For example, V.N. Tsaturov, having compared the traditional philosophical-pedagogical and humanistic paradigms in education, proposes an ethno-humanistic paradigm which is based on a new principle of combining ethnic and world cultural traditions in the process of transmitting cultural and historical experiences to students (Tsaturov, 2000).

V. V. Makayev sees the main purpose of a multicultural approach to education in "conditions for creation a person capable of active and effective life in a multi-ethnic and multicultural environment, possessing a strong sense of understanding and respect for other cultures, ability to live in peace and harmony with people of different nationalities, races, and beliefs." (Makayev, 1999).

According to some Western scholars the main precondition for the development of a multicultural approach to education as a scientific paradigm was the social movement towards granting equal rights to racially and ethnically underrepresented groups in the early $70 \mathrm{~s}$ of the $20^{\text {th }}$ century. For several historical reasons, the period before that was marked by a general lack of access of ethnic minorities to secondary and higher levels of education. Under the pressure from the socio-political movement for desegregation of education, the American government took a number of radical measures which allowed racial and ethnic minorities, predominantly black African Americans, to have access to educational institutions of the traditional ,white majority”.

Therefore, within this context, the term „multicultural education” was initially understood as „multi-ethnic education” - i.e. education for representatives of various mostly underrepresented cultural groups. Subsequently, the supporters of equal rights for racial and ethnic groups were joined by representatives of the feminist movement, and various other sociopolitical groups. That is the main reason that the Western conceptualization of the term „multicultural approach to education” first and foremost means access to education by the representatives of different cultural groups, and the notion of adequate representation of members of these groups in educational settings takes a secondary place on the scale of importance.

Therefore, some Western experts in multicultural education (Adams, 1991; Banks, 1994; Gollnick \& Chinn, 1990) understand culture as a way of life, which a certain group of people follows. As a consequence, American 
educational science (Banks, 2006; Nieto, 2000), among other things, distinguishes racial, ethnic, secular, religious, political and social societal divisions, as well as the culture of youth and adults.

A well-known Russian specialist in multicultural education G.D. Dmitriev also identifies different types of cultures based on: ethnicity (Russian, Jewish, Udmurt, etc.), gender (male, female), ideological views (communist, democratic, and others), economic system (planning, market, natural, and others) and many other parameters (Dmitriev, 1999).

An individual belongs to multiple cultural layers (social, tribal, gender, age, professional, sports, etc.). Viewed from this perspective, a person is a matrix of many different cultures. This is an important underlying principle of multiculturalism within which a student can also be thought of as a repository of several cultures: male-female (gender), urban-rural (community), child-teenager (age), black-white (race), Slavik-Sakha (ethnicity), rich-poor (socio-economics), etc.

\section{Application of a multicultural approach to education in Russia}

Education, therefore, creates the context which presents the opportunity to understand individuals from a wider socio-cultural vantage point. However, education „,can not cover all types of variability in human development and life; it is always based on its own ,invariant" view of the essence of a human being , (Buyeva, 1997). That is, all educational systems have specific socio-cultural roots, which define cultural and linguistic diversity of their students. Therefore, educational systems differ in how they define multi-culturalism.

In light of this, according to various reasons, the focus of a multicultural approach to education in Russia is to first of all provide access to education to representatives of different ethnic groups. However, the problem of ethnic multiculturalism is solved differently depending on the specific geographical area of Russia with in which a given educational system is embedded. Traditionally, the question of a multicultural approach to language education has arisen in regions where there is a substantial concentration of representatives of different ethnic groups (e.g. Southern Urals, Volga region, Northern Caucasus, Western Siberia and the Far East). One solution to the problem of multi-cultural education in such places is to create separate ethnic schools or classes for members of that or the other ethnic community. Thus, in Russia the term ,a multicultural approach to language education" does not necessarily mean the inclusion of representatives of different cultural groups within the same educational context, as it usually does in the West; in Russia it is increasingly used to mean „multi-ethnic.”

The presence of equal opportunities for all ethnic groups to realize their cultural needs in a system of education contributes to the preservation and development of ethnic cultures. „The multicultural model (in education) is 
aimed at preserving and developing the cultural identity of national minorities and minor ethnic groups, study of minor cultures, the publication of books in native languages and related dialects. It encourages inter-ethnic contacts and fosters respect for the values of other cultures. It has a particularly beneficial effect on the younger generation: children learn from each other customs and traditions rather than textbooks; they become acquainted with the cultural geography of the world ..., (Kravchenko, 2001).

A contemporary socio-cultural situation is characterized by the fact that a person is at the boundary of different cultures which demands of him/her continual intercultural interaction through dialogue, understanding the cultural identity of others and developing a cross-cultural awareness. Prejudice against other cultures is a result of cultural ignorance on the basis of which there is a heightened risk of development of ideology of separatism, ethnocentrism and discrimination and socioeconomic and educational spheres are not immune to it. Therefore, there is the urgent need for an effective educational policy aimed at developing positive intercultural relations and prompting educational institutions to include both major and minor ethnic groups in their educational structures. This is believed to facilitate the development of intercultural competence among a younger generation, their ability to function within a larger, national environment, as well as smaller, minor cultural spaces.

In order to prevent xenophobia, it would be helpful to adopt the view of a human being acting as a unity of general (universal), special and individual (personal) factors. In this respect, F.G. Yalalov's three-factor model of an ethnoregional educational systems is worthy of careful consideration. According to this model, the content of education should consist of: 1) an ethno-cultural component with a representative of a particular ethnic group (individual); 2) a cross-cultural component with a representative of the Russian culture (special); and 3) a multicultural component with a representative of the universal human culture (general) (Yalalov, 2002). It is also important that there is a close contact between one's native culture, other cultures and the world community as a whole.

Recent works devoted to the analysis of education reform under the conditions of social crisis, has shown that multicultural education contributes to the preservation and development of cultural diversity. This is reflected in the State Program of National Revival of the Peoples of the Russian Federation and in the National Educational Doctrine, as well as other government documents.

We maintain that the content of education and training should be drawn from the knowledge heritage of national cultures, as well as from the overall experience related to cultural contacts between various ethnic groups. It appears that the most effective way to preserve, develop and self-realize a culture is through contact with the surrounding cultures. Therefore, the core principle of revival and renewal of national identity is based on the idea of the unity of traditions and innovations. 


\section{The main features of a multicultural approach to education}

Thus, the prospects of developing a federal system of education are intimately associated with the main features of a multicultural approach to education. One of them is the principle of dialogue of diverse cultures of which much has been said by V.S Bibler. He argues that culture is ,a space of many spaces”, and "the inside of each culture - art, philosophy, morality, theory" (Bibler, 1991). Here the emphasis is on the simultaneous co-existence and communication between people of different cultures. The accent is on „communication of cultures as a collection of individuals, capable of infinite actualization; that is, the very definition of culture implies communication of different minds across the spectrum ranging from complete misunderstanding to true understanding" (Bibler, 1991). V.S. Biblersuggested a type of dialogue in which all philosophical and cultural systems are accepted as equals and can coexist and interact. According to the concept of the philosopher, every subject of culture must feel incompleteness of being in front of an endless variety of the world culture. In such circumstances the only reasonable way of genuine unity of different cultures can be recognized only a dialogue between them.

All this implies that one becomes aware of culture only through interaction, through a dialogue of different cultures, which can lead to the essential features of all cultures becoming apparent and comprehensible. In modern conditions the interaction of cultures is characterized by the fact that by way of comparison the universal culture can help to understand the objective value of one's own „native" culture and reveal its new modes of functioning, as well as to enable one to make predictions about its further development. In the process of cultural interaction increases the number of perceived values which consequently changes the very nature of perception itself. Perception becomes more ,sharpsighted" and is able to reflect the properties of a cultural object in all of its nuances and details. Isolation and the desire for closure can result in a gradual degradation of a culture. A culture without contact with other cultures preserves its identity at too high cost and runs the risk of descending „below the level of culture" (Stepin, 1991).

Pluralization of cultures is one more foundational principle of a multicultural approach to education. Simply put, pluralism is a theoretical stance, opposed to monism, which maintains that the world is based on many independent spiritual essences. According to some American scholars, cultural pluralism argues not so much for the ontology of cultural diversity, as for the integration and interconnection of different ethnic experiences each of which is equally true and valid (Feiblman, 1987).

There are a lot of manifestations of this conceptual view: decentralization of education, establishment of private, non-governmental educational institutions, introduction of bilingual education, expansion of ways of acquiring knowledge, creation of regional and national educational institutions, 
development and introduction of social science subjects with the multicultural content into the education curricula, formation of global thinking, deepening of national self-knowledge as a fundamental principle of pluralistic worldview (Mukhametzyanova, 1996).

Democratization of the educational system improves the socio-economic development of a society, transforms society, and expands educational space.

Pluralization deepens and fixes democratic achievements, promotes the formation of a new philosophy of life, a new culture of thinking on a universal, global scale, based on a variety of national cultures and plurality of ways of acquiring knowledge; in other words, pluralization is aimed at human development. According to some experts, concerned with the problem of introducing pluralism into the European system of education, profound processes of transformation have taken place, covering the entire system and which have radically changed the traditional role of education (Mutulusa, 1993). Challenges of its humanistic, cultural and international aspects should be considered within a global context; that is to say, in a context which includes the problems affecting the entire world community. Sometimes it happens that some pluralistic concepts, yet not being clearly defined, are still widely used and prove useful in solving important problems. This is equally true to all notions of multiculturalism and pluralization of education.

Indeed, a person should strive for multiculturalism, even if he was brought up and educated in a certain kind of culture and consciously adhered its norms and values. He must be open not only to the existing forms of culture in his society, but also to those which existed in the past, replacing each other in successive generations by means of symbolic systems in all their originality and richness. As a spiritual creature he has the right to choose the direction and content of his spiritual life and the values of the entire cultural repository of humanity. A person can and should perform actions in determining his/her own way of life; he/she should not only adopt to the existing conditions, following the already established rules and traditions, but he/she should also organize life according to his/her chosen values and beliefs while relying on his/her own experience, as well as the experience of others.

\section{Conclusion}

The analysis of the problem of a multicultural approach to education has revealed a number of its essential features: dialogue of cultures in the historical and contemporary context; cultural pluralism; multi-ethnicity.

The idea of intercultural, interethnic pluralistic dialogue, being the basis of a multicultural approach to education, allows us to consider the same phenomenon from different angles and to advance arguments according to the comparative analysis of the ,general" versus ,specific" within their unified dialectical framework. 
Thus, a multicultural approach to education is an educational approach aimed at finding a balance between ethno-cultural diversity and stable social ties, preserving and promoting the variety of ethnic and cultural realities with a view to the progressive development of an individual in a multicultural society. It aims to preserve and promote the diversity of ethnic and cultural values, norms, patterns and forms of activity prevailing in the society, and to transfer this heritage to younger generations.

The cultural picture as a system of different values and cultural patterns is unified not by it's unitarily, but by multiplicity and variety of elements, each of which has a right to exist within it. Thus, a system of education should take into account cultural diversity, dialogical relationships of national and universal values and promote its uniqueness through integration with society.

\section{References}

Adams, J.Q. (1991). Multicultural Education: Strategies for Implementation in Colleges and Universities.Macomb: Western Illinois University.

Banks, J.A. (1994). An Introduction to Multicultural Education. Boston: Allyn\&Bacon.

Banks, J.A. (2006). Cultural Diversity and Education: Foundations, Curriculum, and Teaching. Boston: Pearson Education.

Bibler, V.S. (1991). From Science Study - to the Logic of Culture: Two Philosophical Introductions to the Twenty-First Century. Moscow: Politizdat.

Buyeva, L.L. (1997). Culture and Education. Alma Mater,4, 11-17.

Dmitriev, G.D. (1999). Multicultural Education. Moscow: Narodnoe obrazovanie.

Feibleman, .J.K. (1987). Education and Civilization. New York: Springer Science\&Business Media.

Gollnick, D.M.\&Chinn, P.C. (1990). Multicultural Education in a Pluralistic Society. Columbus: Merrill.

Kravchenko, A.I. (2001). Cultorology: Dictionary. Moscow: Academichesky proekt.

Makayev, V. V. (1999). Multicultural Education - an Urgent Problem. Pedagogics, 4, 3-6.

Mukhametzyanova, G.V. (1996). Strategies for Formation of Secondary Vocational Education. Moscow: Magister.

Mutulusa, T. (1993). Pluralistic Education in Sub-Saharan Africa. Prospects, 2, 47-52.

Nieto, S. (2000). Affirming Diversity: the Sociopolitical Context of Multicultural Education. New York: Longman.

Stepin,V.S. (1991). The Prospects of Civilization: From the Cult of Force to Dialogue and Consent. Ethic thought, 182-199.

Tsaturov, V.N. (2000). Towards the World Culture - Through Education. Multicultural Education in the North Caucasus: Challenges and Prospects, 29-31.

Yalalov, F.G. (2002). School Education of the Peoples of Russia. Kazan: Magarif. 